\title{
Factors Affecting Dividend Policy: An Empirical Investigation of Food Sector of Pakistan
}

\author{
Kamran Ullah \\ MS Finance and Management Sciences, University of Shaheed Zulfikar Ali Bhutto, Institute of science and \\ technology, Islamabad, Department of management Sciences, Pakistan \\ Tanveer Bagh* \\ Finance and Management Scholar at Riphah International University Islamabad, Pakistan, Faculty of \\ Management Sciences, Riphah School of Leadership, MBA Finance, Department of Business Administration \\ (UAJ\&K), Pakistan, Lecturer Banking Finance and Accounting at Indus Group of College \\ Dr.Muhammad Arif \\ $\mathrm{PhD}$ in Corporate Finance, Department of Management Sciences, Assistant Professor, University of Sawabi \\ KPK, Pakistan
}

\begin{abstract}
Dividend policy is considered to be one of the paramount important areas of corporate finance and its real consequences for all the companies and stakeholder. Dividend decision is get affected multiple factors like Leverage, Profitability, Business Risk, Liquidity, Growth Opportunities and other micro and Macro economies variables. On this premise, this study investigates factors affecting dividend policy of non-financial food firms listed in Pakistan Stock Exchange (PSE) by analyzing panel data of 20 non-financial firms for the period of 2011 to 2016. The results from fixed effect model estimation revealed (E-views) that the variables profitability, liquidity and leverage are positively and significantly related to the dividend payout, whereas business risk and growth opportunity are negatively and significantly related to the dividend payout. Therefore, it can be argued that increasing the profitability, liquidity and leverage of the firm ultimately they also increase the dividend payment to shareholder. The study provides valuable information to the Board of Directors for formulating and reviewing the dividend policy, taking into account the factors that have been shown to have a significant impact on the dividend payout. In particular, if the Board of Directors considers increasing the dividend payment to shareholders, the factors of profitability, leverage, liquidity, growth opportunity and business risk must be carefully considered.
\end{abstract}

Keywords: Dividend Payout, Profitability, Liquidity, Leverage, Fixed Effect Model

DOI: $10.7176 /$ RJFA/10-5-02

Publication date:March $31^{\text {st }} 2019$

\section{JEL Classification:}

Corresponding Author; Tanveer Bagh ${ }^{2 *}$, Finance and Management Scholar at Riphah International University Islamabad, Pakistan, Faculty of Management Sciences, Riphah School of Leadership, MBA Finance, Department of Business Administration (UAJ\&K), Pakistan, Lecturer Banking Finance and Accounting at Indus Group of Colleges

\section{1: Introduction}

In the recent years, dividend policy is considered to be one of the paramount important areas of corporate finance and its real consequences for all the companies and stakeholder is not a new phenomenon. It has been explored that companies which are performing well they generating more profit. They have different investment avenues to use this generated profit. According to residual theory of dividend there is a common trend, to reinvest the profit of the companies in the business because of the clientele effect as well as there have been a great pressure on companies to pay dividends. To that respect, Black (1976) stated the more we look at dividends, the more it looks like a puzzle, where the pieces just do not fit. The dividend policy is the most controversial areas of corporate finance. The dividend policy states to the dividend assessment that a manager of a company is prepared to pay dividends to investors or shareholders, commonly known as a dividend per share. The continued distribution of the dividend is important for investors to guarantee a longer holding period for the shares. This means that the decision to pay the dividend on a continuous basis is directly related to the dividend policy. The payment of the dividend to the shareholders is very important to maintain the good image of a company. The decisions to pay the dividend have strong bearing on the profit of the company. Therefore, the company takes some portion of earnings as a retained and the remaining is distributed among the shareholder. Khan et al. (2016) investigated there are three different beliefs of the researcher about the dividend payout. First, there are some researchers who believe that value of the firm increases with the increase in dividend payout ratio they are 
known as conservative group. The second group believes that value of the firm decreases with the increase of dividend payout ratio. Third, there are some theorists who believe that there is no link between firm value and dividend payout (Miller \& Modigliani, 1961; Myers \& Majluf, 1984). It is worth mentioning that mainstream of the studies conducted on the dividend policy in the developed economies. There are very limited studies have been done in the developing countries (especially in Pakistan), as a result creating a huge knowledge gap Khan et al. (2016).In addition, this study aims to find specific financial factors that influence the dividend in Pakistan. Here we have taken the whole food industry as a sample size. The aim of this study is to examine the impact of financial variables and ratios such as leverage, business risk, profitability ratio, liquidity ratio, and growth opportunities on corporate dividend policy. In this study, we use the return on asset (ROA) and the dividend payout ratio as proxy for profitability and dividend policy. For this we use data for the period from 2011 to 2016 and took 16 food companies listed on the Pakistan Stock Exchange.

\subsection{Significance of the study}

The study provides valuable information to the Board of Directors for formulating and reviewing the dividend policy, taking into account the factors that have been shown to have a significant impact on the dividend policy. In particular, if the Board of Directors considers increasing the dividend payment to shareholders, the factors of profitability, debt, liquidity, growth and business risk must be carefully considered. This is important because dividend policy is a key factor in keeping existing investors and attracting new investors. In addition, with high dividend payments attracting investors, the management team must strive for higher profitability, liquidity, leverage, and lower business risk and growth, to maximize the wealth and pay high dividend to shareholder. Since the payment of dividends is a form of reward or return to shareholders, the results of this study provide valuable information to the existing and potential shareholder for making investment decision. The investor wants to invest in a company who has large profitability, liquidity, leverage and lower business risk and growth. Gill et al. (2010) indicated that future research should investigate a generalization of results outside the United States. Therefore, the present study is significance by filling the gap mentioned by (Khan et al., 2016).

\subsection{Problem Statement}

Khan et al. (2016) identified, it has observed that most of the studies on dividend pay-out have been carried out in developed countries of the world but fewer in developing countries like Pakista where the importance of dividend pay-out are yet not well recognised. Dividend policy is the most controversial and widely debited topic in corporate finance. According to Brealy et al. (2008) Controversy over dividend policy is one of the ten unsolved issues of corporate finance that deserve more research to improve understanding of the topic. A number of research studies are being conducted worldwide in this area, but there is no general consensus between them. Research in different countries, which includes almost the same variables but different industries, has yielded slightly different results. Gill, Biger \& Tibrewala (2010) Study the US manufacturing and service industries revealed different significant factors for both industries. For this reason, this research has selected the food industry, an important industry within the Pakistan business environment, to find an industrial specific factor that influences the dividend payout. The logic behind the selection of food sector is dividend payment because most of the firm in the food sector paying dividend. Therefore the food sector is chose for this study. Despite the above considerations, it is also noted that some variables that influence the dividend distribution are perceived in a similar direction. For example, when a company's profitability increases, it is assumed that this increases a company's dividend payout ratio (Mehta, 2012, Nuhu, 2001, Gill, Biger \& Tibrewala, 2010, Zameer et al., 2013), while Jozwiak (2014) found a negative Relationship between profitability and dividend payout ratio. Similar to liquidity, some researcher have concluded a positive relationship Ahmed and Javaid (2009), while other have a negative relationship (Zamer et al., 2013). Ringborg, Dai, and Gardangen (2016) examined in their study further research should test more different determinants of dividend policy that is risk, liquidity and growth. Thus, three factors for future research introduced in present study. There is a dearth in the literature. Therefore, there is a need of meticulous analysis. This study in particular, focuses on "Factors Affecting Dividend Policy on Food sector of Pakistan',

\subsection{Research Question}

1. What is the influence of financial leverage on dividend payout decision of food companies registered on the Pakistan Stock Exchange?

2. What is the influence of current ratio on dividend payout decision of food companies registered on the Pakistan Stock Exchange?

3. What is the influence of Profitability on dividend payout decision of food companies registered on the Pakistan Stock Exchange?

4. What is the impact of growth on dividend payout decision of food companies registered on the Pakistan Stock Exchange? 
5. What is the effect of business risk on dividend payout decision of food companies registered on the Pakistan Stock Exchange?

\subsection{Objectives of the Study}

1. To examine the relationship between financial leverage and dividend payout decision of food companies registered on the Pakistan Stock Exchange.

2. To examine the relationship between current ratio and dividend payout decision of food companies registered on Pakistan Stock Exchange.

3. To examine the relationship of Profitability and dividend payout decision of food companies registered on the Pakistan Stock Exchange.

4. To examine the relationship of growth and dividend payout decision of food companies registered on the Pakistan Stock Exchange.

5. To examine the relationship of business risk and dividend payout decision of food companies registered on the Pakistan Stock Exchange.

\subsection{Delimitation of the study}

It is noteworthy that dividend policy is not only influenced by internal factors but also by external factors (Jensen \& Johnson, 1995, Jensen \& Smith, 1984, Lintner, 1956). Internal factors include investment opportunities, profitability and liquidity, while external factors focus on macroeconomic issues such as growth, stability, technology change and changing consumer tastes Roberto (2002). To disclose the factors of dividend payout policy, we have confined present research to food industry and select factors that may influence the dividend policy of a company. We have decided to examine the association between the dividend payout ratio and leverage, liquidity, return on investment (ROA), risk and opportunity for growth. We have decided to limit the research to these five factors as we have concluded that the above factors are most important to the company's dividend policy.

\section{0: Literature Review}

The dividend policy states to the dividend decision that a manager of a company would pay to shareholders, commonly referred to as dividends per share. The dividend payment is important to investors to ensure a long holding period for equities. This means that the decision to pay the dividend on a continuous basis is directly related to the dividend policy. The payment of the dividend to the shareholders is very important to maintain the good image of a company. The decision to pay the dividend will have a positive impact on the company's income. As a rule, the dividend will be paid from a part of earnings and the remaining is retained. The payment of the dividend shows the ability of the company to bear its own and borrowing costs. Dividend refers to the distribution of profit among the shareholder in the form of profit in achieving the wealth maximization objective of the shareholder. Dividend policy is "the practice that follows by the management to take dividend payout decision on the base of this or, in other it is practice of distribution of cash among the shareholder in a specific time period" (Lease et al.,2000). Dividend policy is an argumentative issue throughout the world it is well acknowledge such as the optimal portion of cash to be distributed as a dividend among the shareholder, but there is a problem of conflict to distribute the earning among the shareholder as a dividend or invest it into a profitable projects. The study done by the Lintner (1956) is one of the earliest studies on dividend policy. The empirical study was conducted on the American companies. They found that current and previous year profitability and dividend are the important factors in determining changes in the current dividend. This is due to the trust of the shareholder because the shareholder is more entrusted in a reasonable rate of dividend. Similarly, Pruitt and Gitman (1991) studied the connection between investment, financing and dividend decision of large firms of USA. They also identified that dividend decision of firms was based on the profitability and previous year dividend. The decisions were not base on the investment and financing decision of the firm. Yousof and Ismail (2014) investigated the factors affecting dividend policy of public listed firms in Malaysia. They found that earnings, firm size and investment positively and significantly related to dividend policy. While debt and large shareholder negatively and significantly related to dividend policy. Since then, there have been a lot of studies conducted on the dividend policy. According to the signaling theory, dividend announcement convey some information about the firm performance that would cause shareholders to react to the announcement (Miller \& Modigliani, 1961). In particular, when the company give indication to pay dividend it was a sign of profitability of the firms. Furthermore, higher the amount of dividend payment, higher will be the profitability of the company (Bhattacharya, 1979). Declaration of dividend payment provides indication of stability of the firm future cash flows (Kale \& Noe, 1990). Charitou (2000) explored the impact of cash flows on dividend payment of firm in japan. The found that earnings were positively related to the dividend changes (in case company faces losses then they were reduced dividend payment). Similarly, they pound also that cash flow were positively related to the dividend payment. The above results was also supported by (Al-Malkawi,2007; Kowalewski et al. 
2007; Anil \& Kapoor, 2008; Juma,h \& Pacheco, 2008; Ahmed \& Javid, 2009; Ramli, 2010; Mehrani et al. 2011; and Hashemi \& Zadeh, 2012). In contrast, Gill et al. (2010) identified that earnings were negatively and significantly related to the dividend policy. Similarly, Anil and Kapoor (2005) and Appannan and Sim (2011) found also negative relationship between earnings and dividend policy. Agency cost theory, was focused to eliminate the cost problem between principal and agent. According to the agency cost theory dividend payment was a possible solution for reducing the agency costs, relevant to some factors that are free cash flow, debt financing, firm growth, investment opportunities, firm size, large shareholders and risks (Jenson \& Meckling, 1976; Rozeff, 1982; Jensen, 1986; Utami\& Inanga, 2011). Dhiensiri (2009) investigated the factors affecting dividend policy of listed firm in the New Zealand Stock Exchange. They found that a free cash flow has a positive and significant impact on dividend payment. However, Imran (2011) and Utami and Inanga (2011) found significant and negative relationship between cash flow and dividend policy. The studies done by $\mathrm{Al}$ Kuwari (2010); Al Shubiri (2011) and Mehrani et al. (2011)found insignificant relationship between cash flow and dividend policy. However, a firm makes debt financing, they needed more cash to meet debt obligation. They ultimately reduce the income and therefore pay low rate of dividend to shareholder.

Al-Malkawi (2007) investigated the factors effecting corporate dividend policy of listed companies in Jordon. They found that debt financing were negatively and significantly related to the dividend policy. The similar results were also found by (Kowalewski et al.,2007; Ramli, 2010; Al-Shubiri, 2011). In contrast, they found that debt financing were positively and significantly related to the dividend payout policy chag and Rhee(1990); Appannan \& Sim (2011) and Gill et al.(2010). According to these studies when a companies have more debt financing, the higher the dividend payment. However, the studies by (Ahmed and Javid (2009); AlKuwari (2010); Gill et al. (2010); Foroghi et al. (2011); Mehrani et al., 2011) and Al-shabibi and Ramesh (2011) found insignificant relationship between debt and dividend policy. Gakumo and Nanjala (2016) explored factors affecting dividend payout decision of financial and non-financial firms registered in Nairobi Securities Exchange. They examined both the dividend payment and dividend payout decision. The study found that earning per share, business risk, and financial leverage play a very significant role in taking decision to pay the dividend or not. Furthermore, they found that earning per share was positively and significantly related to the decision to pay while both the business risk and financial leverage negatively affected the dividend payout decision. Imran (2011) identified the factors of dividend policy in engineering firms from 1996 to 2008. They used fixed effects and random effects approach. They found a positive relationship of dividend per share with previous year dividend, and also found a negative impact of earning per share, sales growth, size, profitability of the firm with cash flow. The results investigated a negative relationship between dividend payment and cash flow, which propose to reinvest their spare cash. They also identified that a company have larger sale and profitability they distributed more cash among the shareholder as a dividend. The firm was not wanted to pay fewer dividends as compared to their previous year. Khan, Naeem, Rizwan, and Salman (2016) examined the factors that influence dividend policy. The findings indicated that the profitability was negatively and significantly related to the dividend payment. There was also a high negative significant impact of leverage on dividend payout ratio (it means that high debt financing firm does not paid dividend). They retain the income to reinvest it in profitable projects. They also found that liquidity negatively related to dividend payout. The finding suggested that dividend payout ratio was no relationship with price earning $(\mathrm{P} / \mathrm{E})$ ratio and firm size. They take 60 textile firms out of 156 from Pakistan Stock Exchange, selected these firms randomly, and used fixed effects mode for analysis.

Amidu and Abur (2006) investigated the determinants of dividend payout policy of registered firms of Ghana. The data was taken from the financial statement of registered companies on the GSE for the period of six year. They used the ordinary least square method. They found that profitability, cash flow, and tax were positively related to the dividend payout. The results found that risk, growth, market-to-book value and institutional shareholding were negative association to the dividend policy. Perretti, Allen, and Weeks (2013) explored the determinants of dividend policy for ADR firms. They found that size, earned and contributed capital mix, and growth play very important role in the decision to pay dividend by ADR firms. The study also suggested, that with the increase of profit the risk was eliminated, and therefore the ADR firms paid fewer dividends. Gul, khan, and Rehan (2013) investigated the factors affecting dividend payout decision. The finding indicated that earning per share, liquidity, size and profitability were positively related to the dividend payout decision,while sale growth was negative relationship to the dividend payout decision. Furthermore, financial leverage was also negatively related to the payout ratio. They used in their study propose and probit model for the analysis of dividend policy. They were taken KSE 100 financial and non-financial firm in their study. Sanjari and Zarei (2015) examined the factors influencing dividend policy and taken financial and non-financial companies registered in Tehran stock exchange. They found that liquidity, leverage, and company size were significantly and positively related to the dividend payment, whereas profitability and growth were negative and significant relationship to the dividend policy. They further found that company grown the dividend payment with the increase of leverage, liquidity, and company size. Thecompany declines the dividend payment with the increase of growth and profitability. They were took 70 financial and non-financial firms registered with Tehran 
Stock Exchange from 2009 to 2013. They used multiple regression method for their analysis.

Bushra and Mirza (2015) investigated the determinants of dividend policy. They used two model yield and dividend payout model for the analysis of dividend payout. They found that return on equity (ROE) and return on asset (ROA) were a positive significant relationship with dividend payment. The firms earned more income they were paid more dividends. The firm size was negative and significant relationship with dividend payment, large firm were large liabilities. Furthermore, sales growth had positive significant relationship with dividend payout. Ownership concentration was also significant relationship with dividend payout. They further found thatgrowth was negatively related with dividend payment. They were took 75 firms out of KSE 100 and the data from 2005 to 2010. Ahmad and Javid (2009) found that a company were low profitable they paid low dividend. They also explored that leverage and growth were negatively related to the dividend payment. They were taken non-financial firms registered in KSE for the period of 2001 to 2006. Similarly Ahmad and Javid (2010) used the same data and found a negative relationship between dividend payment and concentration within the management and individuals. Asghar, Shah, Hamid, and Suleman (2011) investigated the effect of dividend payout decision on stock prices. The data were taken of five sector of non-financial from 2005 to 2009 . The results were foundthat price instability and firm size were positively and significantly related to the dividend payment and dividend yield. Dennis (2008) investigated that company earn income and distributed it in two significant parts, first they invested their income in company. Secondly they distributed the income between the shareholders as a dividend. The companies which paid dividend to shareholder they made more financing from external sources which affect the stock price of a company. There are some shareholder who wanted to distribute some part of the profit among the investor and some part of the profit took as retained earnings. They were invested this income in profitable projects in future (Anil, 2008). Manao and Nur (2001) examined the relationship between financial ratios and stock performance in Indonesia during the economic crisis. They identified that earning per share (EPS) was significantly related dividend payout ratio. Baker et al. (2007) found that several Canadian companies pay significantly higher dividends with higher profits. They have tremendous positive cash flows, growth opportunities and larger ownership structure. Ho (2003) identified a study in Australia and Japan on dividend policy. They found that size was positively related to dividend policy in Australia and liquidity was positively related to dividend policy in Japan. They also found that risk was negatively related to dividend policy in only Japan. In addition, the industry effect was significant in both countries. Ayub (2005) examined the impact of company-specific factors on corporate dividend payments. They found a positive relationship between the dividend payout and profitability, ownership and retained earnings and also negative association between liquidity and dividend payout ratio. Out of 180 firms registered on the KSE between 1981 and 2002, only $23 \%$ of firm paid their profit as a dividend. After achieving some growth through additional investment from profits, companies start to pay dividends. Ahmad and Attiya (2009) identified the factors affecting dividend policy shows that financial sound firm paid more dividends. They found that market liquidity and ownership concentration were positively and size was negatively related to the dividend payment. And growth opportunities have no relationship with dividend payment. Similarly, Afza and Mirza (2010) identified the factors of dividend payout policy. They investigated that profitability and operating cash flow were positively related to the dividend payout policy. While cash flow, ownership, leverage and size were negatively related to the dividend payout policy. Denis and Osobov (2008) explored the policy of dividends in different countries between 1989 and 2002. In theCanada, United States, the United Kingdom,Japan, Germany and France, the largest and most lucrative companies tend to paidlarger dividends. Outside the United States, however, there is smallproof of a positive connection between dividend payments and companies that do not pay. Renneboog and Szilagyi (2008) compare European companies that pay lower dividends with US market-oriented companies. They discover that the payments of the Dutch companies were smaller because they used their authority against the requirements of the shareholders. The catering theory of Baker and Wurgler (2004) examined that company directors should offer incentives to their owners according to their requirements. They should look after shareholders in the best possible way to pay straight dividends. Otherwise do not pay dividends when investors prefer companies that do not pay. Skinner and Soltes (2011) investigated payment patterns for performance quality that were not alter over time. The sample is comprised of all companies registered on the NYSE (excluding utility and utility companies) between 1974 and 2005. They found that companies paid dividends reported fewer due to losses: investors tended to invest in companies, which gave a regular pattern of dividends.

Khang and King (2006) explored the allegations of irregular information. They found that company's insiders have an information advantage when trading stocks. This disturbs the company dividend policy. They were used sample of firms for 1982-95, they found that larger a company dividends, the smaller the insider profit. Farinha (2003) identified the Agency problem of dividend policy for UK companies. They found that cash payments to shareholders help decrease the agency's problem in two ways: (i) increasing leverage or (ii) decreasing the FCF. They were taken the data of 600 companies two five year period (1987-91 and 1992-96). They found that domestic ownership strongly related to the dividend policy. 
Kumar (2006) investigated the association between ownership structure, corporate governance and dividend distribution policy, in the developing Indian market. They were taken the data of 2575 listed companies from 1994 to 2000. They found that ownership is significant factor of dividend policy. They also found that Institutional owners were negatively related to the dividend policy. The foreign ownership and dividend payout ratio found no relationship. Afza and Mirza (2011) examined the relationship between dividend payout policy and institutional shareholding. They found that institutional ownership was positively related to the return on equity (ROE), and negatively related to sales growth. They were taken 120 companies for the period of 2002 to 2007 Nazir, Nawaz, Anwar, and Ahmed (2010) identified the role of dividend policy in determining the instability of share prices in Pakistan. They found that dividend policies were positively and significantly related to the stock price volatility. They were run fixed effect and random effect model on the data. They have taken the data of 73 listed firms from 2003 to 2008. Asghar, Shah, Hamid, and Suleman (2011) investigated the effect of dividend payout on shares price. They have taken the data of five non-financial firms (synthetic fibers, sugar, cement, engineering, and chemical) from 2005 to 2009. They found that dividend payout and dividend yield was positively and significantly related to the stock price and firm size.

Musiega, Alala, Douglas, Christopher, and Robert (2013) identified the determinants of dividend policy of non-financial sector of Kenya. They found that earning, growth, and return on equity were positively related to the dividend policy. They were took the non-financial firm for the period of 2007 to 2011. Almeida, Pereira, Tavares, and Porto (2014) identified the determinants of dividend policy of Portugal non-financial firm. They found that previous year dividend and larger size were positively related to the dividend policy, whereas net income and debt were negatively related to the dividend policy. They were took the data from 1997 to 2011 , and used multiple linear regressions method. Soondur, Maunick, and Sewak (2016) reported the determinants of dividend policy of listed companies of Mauritius Stock Exchange. They found that net income positively related to the dividend payout ratio, whereas retained earnings were negative related to the dividend policy. They were used fixed and the random effect model for the analysis of data. By considering 30 non-financial, Arif and Akbar (2013) explored the determinants of dividend policy and took non-financial companies listed in Pakistan Stock Exchange. They found that size, profitability and investment opportunities were positively related to the dividend policy, whereas tax were found negatively related to the dividend policy. They were took 174 nonfinancial registered firm from 2005 to 2010. Olantundun (2000) explored the factors affecting dividend Nigeria using the Lintner-Brittain model. The ordinary least square (OLS) method was used. They found that dividend decision was insignificantly related to the Lintner- Brittian model. They also found that the performance of the dividends of Nigerian companies depends on the growth prospects, the gear and the size of the company. Kumar (2003) investigated the relationship between corporate governance, ownership structure and the firm dividend policy. They found that earnings and investment opportunities were positively related to the dividend policy in India. The Debt-to- equity was negatively related to the dividend policy. Kuwari (2009) examined the determinants of dividend policy. They were taken nonfinancial firm registered on the Gulf Co-operation Council (GCC). The found in their study that companies pay dividends to reduce the agency problem. The companies listed in the GCC countries often change their dividend payout policy and do not pursue a long-term dividend payout policy. They found that firm size, government ownership and profitability were significantly and positively related to the dividend policy. They found also that leverage was negatively related to the dividend policy. Anil and Kapoor (2008) identified the factors of dividend payout ratio. They were took the Information Technology sector of India for the period of 2000 to 2006. They found that corporate tax, market to book value, cash flows and sales growth have no impact on the dividend payment. They found that only liquidity have an impact on dividend payout ratio. Al-Twaijry (2007) explored the emerging market of Malaysia. The study found that present dividends were influenced by the previous and the upcoming. Dividends were also linked to net income, but not so much. They found that size were significantly related to the dividend per share (DPS) compared to present, previous or upcoming net income.

Appannan and Sim (2011) examined the determinants of dividend policy in Malaysia. They found that profit after tax was high positively related to the dividend per share. They also identified that previous dividend per share and leverage were the significant factors of dividend payout ratio. Kasim Alli, Qayyum Khan, Gabriel Ramirez. (1993) identified the determinants of corporate dividend policy. They found that residual theory, pecking order theory and role of dividends strongly supported reducing the issues of the agencies. They also found that companies with financial flexibility that have stable dividends payout ratio. Elton and Gurber (1970); Lintzenberger and Ramaswamy (1979); Brennan (1990) and DeAngelo and Masulis (1980) explored the tax clientele argument. They found that investors preferred high dividend due to low rate of tax, as compared to the high tax rate. Study by Sterk and Vandenberg (1990) found that investors give preference to the cash dividend when the tax was eliminated between capital gains and dividend income. Company size and profitability were most commonly examined factors in terms of dividends. Jensen and Meckling (1976) and Jensen, Donald and Zorn (1992) found that high profitable companies would rather rise their dividend payments. Smith and Watts (1992) found that size and dividend payout were positive relationship used industry-level data. Fama and French 
(2001) identified the determinants of dividend policy one of the most cited study. They found that the largest and most profitable companies have a higher dividend payment. As a result, size and profit were positively related to the dividend payout policy. DeAngelo, DeAngelo, and Skinner (2004) expanded the Fama and French study in (2001). They were emphasis dividend specially. The results of DeAngelo and Skinner were same to the Fama and French (2001). They found that larger scale and earnings were significant association with dividend payout ratio. The similar result was also found by Denis and Osobov's (2008).

Skinner and Soltes (2011) found the positive relationship between size and dividend payout ratio.Grullon, Michaely, and Swaminathan (2002) identified that profitability were a negative impact on the dividend payout ratio. Investment opportunities and growth affect the dividend payout policy of companies. Companies with towering growth potential tend to retain the funds generated internally and to use them to finance their funds (Rozeff, 1982a; Myers \& Majluf, 1984; Jensen et al., 1992). Therefore, they found that growth opportunities were negatively related to the dividend policy. Smith and Watts (1992) found that groth were negatively related to the dividend yield of companies. Gaver and Gaver (1993) found that high growth firms were lower dividend yield and dividend payout ratio. The similar results were also found by the Fama and French (2001). Michel (1979) examined the firm industry impact on dividend policy. They found that classification of the industry were positive relationship to the dividend payout. Rozeff (1982b) found insignificant impact of industry on the dividend policy. Baker, Farrelly, and Edelman (1985) identified the industry impact on the dividend policy. They found that there are three major industrial groups: utilities, manufacturers and wholesalers and retailers. They stated that utilities have lofty payout ratios and utilities dividend decisions are different. They attribute it to the regulated nature of the public service industry. But because of monopoly power and the non-competitive environment in the industry, utility companies see the world differently. The similar result was also found by Baker and Powell (1999).

It is expected that high leverage companies have low payment ratio. To reduce the transaction cost highdebt companies pay lower dividends Jensen et al. (1992). Smith and Watts (1992) and Gaver and Gaver (1993) found that leverage were positively related to the dividend payout ratio. They also found thatcompanies growth have inverse association with debt and dividend payout ratio. Grullon et al. (2002) identified changes between systematic risk and dividend. They found inverse relationship between systematic risk and dividend. The reason for his research was that investment opportunities decreased as companies matured.

Yurtoglu (2000) explored the Turkish registered company's ownership structure. They found that ownership was negatively related to the return on asset, dividend payout and price to book ratio. Therefore, he suggested that focusing on the ownership of the company would have a negative impact on the performance of listed companies. They used firm performance as a proxy for dividend payment, return on asset and price to book ratio. He believed that the return on investment of smaller shareholders was determined by the payout ratio.

Aivazian, Booth and Cleary (2003) investigated the factors affecting dividend policy in eight developing markets, as well as Turkey. They equate the behavior of the dividends of developing market companies with those of the US. They suggested that companies in developing markets pursue an unstable dividend policy. Litzenberger and Ramaswamy (1979) found inverse relationship between dividend and firm value. Lintner (1962) found that with the increase of dividend the market value of firm also increased. The similar result was found by the Glen et al. (1995). Dybvig and Zender (1991) found that the dividend payout ratio reflects the return on equity and that a dividend distribution finally benefits the stockholders. Therefore, the dividend payment averts the company from the agency problem. The idea that dividend payment can reduce agency problems was also braced by other scholars like Easterbook, (1984). Likewise, Jensen (1986) found that the amount paid to the shareholder in the form of dividends discourages management to spend it on the activities that best suit them, ultimately, reducethe problem of the agency. Farrelly and Edelman (1986) identified the relationship between future earnings and dividend. They found that future earnings are positively correlated to the dividend payout ratio. The board of directors designs the dividend policy on the basis of earnings. Dividend payment represents the positive sign of future earning related to the firm. While lower dividend payment indicate negative sign when company retain the earning for future investments. Pruitt and Gitman (1991) examined that the distribution of dividends is based on present and upcoming earnings. Huda and Farah (2011) identified that decision to dividends payment in the banking sector depends on retained earnings, earnings per share, income and cash. Marfo-Yiadom and Agyei (2011) explored the dividend policy in Ghana banking sector was based on profits, collateral capacity, leverage, and growth rate. Lee (2009) explored that risk and profit were significantly impacted dividend policy in the banking sector of koria. Deshmukh et al. (2013) found negative relationship between leverage and dividend policy. However debt financing increase the cost of interest and Aivazian et al. (2001) found that risk and debt were negatively influenc the dividend payout policy. Al-Kuwari (2009) identified that size were positively influence the dividend payout ratio. They also found that leverage was negatively related to the dividend payout ratio. Jabbouri (2016) found that liquidity, size and profitability were a positive impact on dividend payout ratio. Mat, mokhtar, Ali, Kasim, and Zaini (2017) identified the factors affecting dividend policy of Malaysian public listed companies. The found a positive relationship between dividend policy 
and growth, firm size, investment opportunity, earnings and cash flow, whereas debt were negatively related to the dividend policy. They were took 26 registeredfirms in Bursa Malaysia for the period of 2005 to 2015. Bogna Kazmierska Jozwiaka (2014) identified the determinants of dividend policy of polish registeredfirms. They found that leverage and profitability were negatively related to the dividend policy. They were took the data from 2000 to 2012 and used random effect model. Anupam Mehta (2012) identified the determinants of dividend policy. They found a positive and significant effect of profitability and size of the firm on the dividend policy decision. They were took 149 registered companies of Abu Dhabi Stock Exchange from 2005-2009. Nnadi, Wogboroma, and Kabel (2012) identified Determinants of Dividend Policy of listed African firm. They found that leverage and agency cost were negatively related to the dividend policy, whereas the ownership structure and age of the firm were positively related to the dividend policy. They were took the data from 29 stock exchange of Africa from 1998 to 2009.

Narman Kuzucul (2015) explored the determinants of dividend policy of Turkish listed firm.They investigated that size, age and price earnings ratio $(\mathrm{P} / \mathrm{E})$ ratio were positively related to the dividend policy, whereas profitability, leverage, family control and growth rate were negatively related to the dividend policy. They were took the data from 2006 to 2013 and fixed-effects and OLS regression model.Adhikari (2015) identified the determinants of dividend payout in Nepal. They found that profitability and liquidity were positively related to the dividend payout ratio, whereas size were negatively related to the dividend payout ratio. They were took 22 companies registered in Nepal Stock Exchange from 2009 to 2013 and used pooled ordinary least square method (OLS) for data analysis. Forti, Peixoto, and Alves (2015) identified the determinant factors of dividend Payments in Brazil. They found that size, return on assets (ROA), market to book, liquidity and profit growth were positively related to the dividend policy. It can be concluded that the company's larger size, profitability, market value, liquidity and earnings growth were correlated with a highertendency to pay dividend to stockholders, supporting the theory of corporate finance. They also examined that debt and risk were negatively related to the dividend policy. They used Tobit and Generalized Method of Moments (GMM) and took the data from 1995 to 2011.

Ahmad and Muqaddas (2016) examined the determinants of dividend policy of banking sector of Pakistan. They found that safety and profitability were positively related to the dividend policy, whereas financial efficiency and risk were negatively related to the dividend policy. They were took 10 banksregistered with Pakistan Stock Exchange (PSX) from 2006 to 2014. Dr. Bahaa Awad (2015) identified the determinants of dividend policy in Kuwait Stock Exchange (KSE). They found that size, profitability and financial leverage were positively related to the dividend policy. They were took 56 financial companies listed in Kuwait stock exchange from 2011 to 2014 and used OLS regression method. Holder, Langrehr, and Hexter (1998) explored the determinants of corporate dividend payout of United States (US). They were found positive relationship between number of shareholder and dividend payout, whereas negative relationship were found between risk, growth and dividend payout ratio. By considering 477 firms Ramli (2010) examined the determinants of dividend policy of Malaysia. They found that the large number of shareholder were positively related to the dividend policy, whereas risk were negatively related to the dividend policy..

Khan et al. (2016) stated, it has observed that most of the studies on dividend pay-out have been carried out in developed countries of the world but fewer in developing countries like Pakistan where the importance of dividend pay-out are yet not well recognised. Dividend policy is the most controversial and widely debited topic in corporate finance. According to Brealy et al. (2008) Controversy over dividend policy is one of the ten unsolved issues of corporate finance that deserve more research to improve understanding of the topic. A number of research studies are being conducted worldwide in this area, but there is no general consensus between them. 


\section{Research Model /Theoretical Framework}

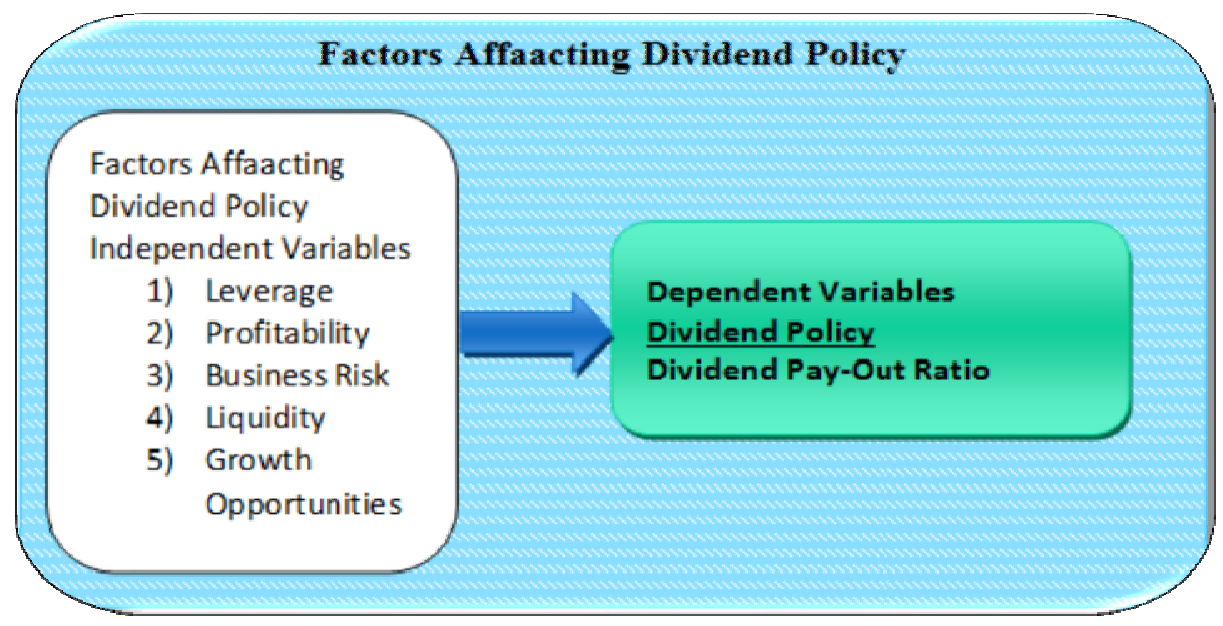

\subsection{Growth Opportunities}

In short, the dividend payment increases with the decrease in growth. Ahmed and Javid (2009), Al-Kuwari (2010) and Jensen (1986) found that the growth of the company increases if the economic opportunities available in the market. Therefore they paid lower dividend to the shareholder. Al-Malkawi (2007) identified that that growth was positively and significantly related to the dividend policy. Therefore, higher the growth of the company higher will be the dividend payout ratio.

$H_{1}$ : There is a negative relationship between Dividend Policy and Growth of the firm.

\subsection{Profitability}

Previous researcher explored that profitability as the most important factor of dividend policy. According to pecking order theory, the firm will prefer to invest retained earnings as a result they paying low dividend (Mehta, 2012; Amidu and Abor, 2006) identified that profitability negatively and significantly related to the dividend payout. That shows firm invested their profit rather than to pay dividend. Similarly, Kania and Bacon explored that greater the return on firm equity the greater the return retained earnings as well as the smaller the dividend payout. Aivazain, Booth and Cleary (2003) examined that firm paid more dividend if they large and profitable.

H2: There is a positive relationship between Dividend Policy and Profitability of the firm.

\subsection{Business Risk}

The price earnings ratio $(\mathrm{P} / \mathrm{E})$ indirectly integrates the predetermined risk of a underlying companies prospect earnings (Fama and French, 1998; Puckett, 1964) investigated that higher the price earnings ratio the higher the earning growth in future as compared to lower price earningsratio. Raising dividends decline the risk of projected cash flows to the stockholder which intern increases stock prices. Consequently, increases prices of the stocks and the P/E ratio. High price earnings ratio reduces the risk and increase the dividend. Abidu and abor (2006) identified that risk is negatively related to the dividend payout ratio.

\section{H3: There is a negative relationship between Dividend Policy and Risk of the firm.}

\subsection{Leverage}

The empirical evidence from past studies showing the liaison between leverage and dividend payout is mixed. (Rozeff, 1982; Mehta, 2012) explored that high financial leverage negatively related to the dividend payout. Likewise, Al-Malkawi (2007) found that financial leverage was negatively and significantly associated to the dividend payout. Kania and Bacon (2005) identified that leverage positively and statistically significantly connected to the dividend payout.

$\mathrm{H}_{4}$ : There is a positive relationship between Dividend Policy and Leverage of the firm.

\subsection{Liquidity}

The liquidity is also regarded as important factors of dividend payouts. Higher liquidity of firm increased the dividend payout as compared to the lower liquidity. Dividend payment highly depends on cash flow which shows ability of the firm to pay dividend. A poor liquidity state of affairs means that firm pays fewer dividends the reason behind the shortage of dividend (Kanwal \& Kapoor 2008; Ahmed \& Javid 2009).

H5: There is a positive relationship between Dividend Policy and Liquidity of the firm. 


\section{0:Research Methodology}

\subsection{Data Description and Sample Selection}

The study has analyzed the 20 food companies listed on Pakistan Stock Exchange (PSX). Population for this study is all registered food companies listed (PSX). Time frame for the study is six year from 2011 to 2016 . The data collected from the annual reports of the food companies' listed (PSX).That is available on the websites of these food companies and also on the Pakistan Stock Exchange (PSX). Secondary data has used in this study. Quantitative research approach has used to conduct this research study. The results based on some statistical method. In this research study the unit of analysis is the listed food companies in Pakistan. For this research study analysis we used E-views software methods to answers the questions.

Table 4.1

Formulation of Dependent and Independent Variables

\begin{tabular}{|c|c|c|c|}
\hline Variables & Variable Name & Description & Empirical evidence \\
\hline$L E$ & Leverage & $\begin{array}{l}\text { Total Liabilities / Total } \\
\text { Assets }\end{array}$ & (Кuzuzh, N.(2015) \\
\hline PRO & Profitability & Net Profit / Total Assets & $\begin{array}{l}\text { Eduardo K.Kayo } \\
\text { and Herbert Kimura } \\
\text { (2011) }\end{array}$ \\
\hline$B R$ & $\begin{array}{l}\text { Business } \\
\text { Risk }\end{array}$ & $\begin{array}{l}\text { (Current year net profit - } \\
\text { Previous year net profit) } \\
\text { /previous year net profit }\end{array}$ & $\begin{array}{l}\text { (Kania and Bacon } \\
\text { 2005) }\end{array}$ \\
\hline$L I Q$ & Liquidity & $\begin{array}{l}\text { Current Assets / Current } \\
\text { Liabilities }\end{array}$ & $\begin{array}{l}\text { Sharon L. Kania } \\
\text { (2005) }\end{array}$ \\
\hline$G R$ & Growth & $\begin{array}{l}\text { Current year asset - } \\
\text { Previous year asset/ } \\
\text { Previous year asset }\end{array}$ & $\begin{array}{l}\text { Sayılgan, } \\
\text { Karabacak, } \\
\text { Kucukkocao (2006) }\end{array}$ \\
\hline$D P$ & $\begin{array}{l}\text { Dividend } \\
\text { Payout }\end{array}$ & Dividend/Net income & Rafique, M. (2012) \\
\hline
\end{tabular}

This study resulted as in numeric form and on basis of our results we suggested the recommendations. Since the main purpose of the study is to examine the factors effecting dividend policy of food companies. The explanatory variables used in the study are leverage, profitability, business risk, liquidity and growth. The detailed description of variables is given in the above table.

\subsection{The Estimation Method}

Dividend policy is a function of financial leverage, profitability, business risk, liquidity, and firm growth opportunities. The following model employed in order to perform factors effecting dividend policy. For data analysis E-views software has used.

$$
\begin{aligned}
D P_{i, t}=\beta_{0}+ & \beta_{1} L E_{i, t}+\beta_{2} P R O_{i, t}+\beta_{4} B R_{i, t}+\beta_{5} L I Q_{i, t}++\beta_{5} G R_{i, t} \\
& +\varepsilon i, t \quad \ldots \quad \ldots l
\end{aligned}
$$

Where, DP is denoted with dividend payout ratio, is dependent variable calculated from dividend / net income for firm $\mathrm{i}$ in period t. LE is the leverage ratio, PRO is the profitability ratio, BR denotes the business risk, LIQ is the liquidity ratio and GR is the growth, $\beta_{0}$ is the intercept and $\varepsilon$ is the disturbance term of firm i in period t. The disturbance term having zero mean and constant variance

\subsubsection{Dividend Payout Ratio}

Rafique (2012) examined factors affecting dividend payout in Pakistan. They found a positive and statistically significant relationship between firm size and corporate tax, whereas profitability, leverage, growth and earning were no impact on dividend payout ratio. The measure the dividend payout ratio with the formula of dividend divided by net income (dividend/net income).

\section{Dividend Payout Ratio $i, t=$ dividend/net income for firm $\mathrm{i}$ in period $\mathrm{t}$,}

\subsubsection{Leverage Ratio}

Mat, Mokhtar, Ali, Kasim and Zaini (2017) explored the factors of dividend policy in Malaysia. The found that growth, firm size, investment opportunity, earnings and cash flow were significantly influence dividend policy, whereas debt were negatively related to the dividend policy. They calculated leverage ratio by using formula of total liability divided by total asset (total liability/total asset)

Leverage Ratio $i_{z} t=$ total liability/total asset for firm i in period $t$, 


\subsubsection{Profitability Ratio}

Eduardo K.Kayo and Herbert Kimura (2011) identified hierarchical determinants of capital structure. They were measured the profitability ratio in their study with the formula of net profit divided by total asset (net profit/total asset)

\section{Profitability Ratio $i, t=$ net profit/total asset for firm $\mathrm{i}$ in period $\mathrm{t}$,}

\subsubsection{Liquidity Ratio}

Sharon L. Kania (2005) examined the factor motivate the corporate dividend decision. They stated that risk, growth, liquidity, profitability, expansion and inside ownership were negatively and significantly affected the dividend policy, whereas profitability growth and leverage were a positive impact on dividend payout. They were measure the liquidity ratio current asset divided by current liability (current asset/current liability).

\section{Liquidity Ratio $i, t=$ current asset/current liability for firm $i$ in period $t$,}

\subsubsection{Growth Opportunity}

Sayılgan, Karabacak, Kucukkocao (2006) explored the firm specific determinants of corporate capital structure in Turkish. They identified that growth opportunity and size were positively related to the debt level, whereas non-debt tax shields, tangibility, growth opportunities in plant, property and equipment and profitability were negatively related to the leverage ratio. They measured the growth with the formula of (Current Year AssetPrevious Year Asset/Previous year Asset).

\subsubsection{Business Risk}

Rafique, M. (2012) they measure the business risk with the formula of dividend divided by net income (Dividend / Net Profit)

\section{0: Empirical Results and Discussion}

\subsection{Descriptive Statistics}

According to the Table 2 the mean and slandered deviation of dependent variable that represents dividend payout policy which is measured by dividend paid divided by net profit 0.298 and 0.394 which indicate that average dividend payout ratio in the sector is 0.29 and the variation from the mean value in the sector are 0.394 .

Table 4.2

Descriptive Statistics

\begin{tabular}{cccccc}
\hline Variables & Mean & Median & Max & Min & SD \\
\hline DP & 0.298 & 0.133 & 1.607 & -0.076 & 0.394 \\
BR & 0.151 & 0.110 & 3.213 & -4.553 & 1.017 \\
GR & 0.155 & 0.114 & 1.183 & -0.893 & 0.256 \\
LE & 0.488 & 0.530 & 1.105 & 0.000 & 0.256 \\
LIQ & 5.669 & 1.407 & 138.519 & 0.000 & 18.019 \\
PRO & 0.076 & 0.060 & 0.462 & -0.220 & 0.102 \\
\hline
\end{tabular}

\section{Descriptive statistics Interpretation}

Descriptive statistics about the dividend payout policy define that dividend payout are not fixed and variation in them is high according to the policy of the firm. The minimum and maximum value of variable is -0.07 and 1.607. The mean (0.076) and standard deviation (0.102) of independent variable which is profitability that is measured by (Net profit divided by total asset). The average profitability in the sector is 0.076 and the variation from the mean profit across the sector is 0.102 . This shows that more companies earn comfortable profit in the sector. The minimum and maximum value of the variable is -0.220 and 0.462 . The mean and standard deviation of another independent variable which is business risk that is calculated by (Current year profit - previous year net profit) / previous year net profit is 0.151 and 0.1 .017 respectively which in turn indicates that average business risk in the sector is 0.151 and the variation from the mean is 0.102 . This represents that, highly-risky firms pay less dividends to their shareholders. The minimum and maximum values of the variable are -4.553 and 3.213. The mean and standard deviation of independent variable growth opportunities that is computed by (Current year net asset - previous year net asset) / previous year net asset is 0.155 and 0.256 respectively which shows that average growth opportunities in the sector is 0.155 and the variation from the mean is 0.256 . This indicates that growing firm needs more funds to finance their growth. Therefore they would retain large proportion of their earning and pay low dividend. The minimum and maximum value of the variable is -0.893 and 1.183. The mean and standard deviation of leverage which is computed by total liability divided by total asset is 0.488 and 0.256 which shows that average leverage in the sector is 0.488 and the variation from the mean is 0.256 . However, this represents that a company were made more debt financing, they can receive tax shield on their profit. Therefore they paid more dividends to their shareholder. The minimum and maximum value of the variable is 0.000 and 1.105 respectively. The mean and standard deviation of liquidity which is measured by current asset divided by current liability is 5.669 and 18.019 which shows that average liquidity in the sector is 5.669 and the variation from the mean is 18.019. This indicate that a good liquidity state of affairs enable the 
firm to pay dividend. The minimum and maximum value of the variable is 0.000 and 138.519 .

\subsection{Correlation}

The table 4.3 represents the relationship between the variables. The findings showed that all the explanatory variables are not highly correlated with each other. The correlation between two variables should not be greater than +0.75 otherwise there are chances of multi-collinearity in the data.

Table 4.3

Correlation

\begin{tabular}{lcccccc}
\hline & DP & BR & GR & LE & LIQ & PRO \\
\hline DP & 1.000 & & & & & \\
BR & -0.146 & 1.000 & & & & \\
GR & -0.218 & 0.115 & 1.00 & & & \\
LE & -0.009 & 0.009 & 0.184 & 1.000 & & \\
LIQ & 0.290 & -0.101 & -0.046 & -0.408 & 1.000 & \\
PRO & 0.314 & 0.347 & -0.016 & -0.101 & -0.045 & 1.000 \\
\hline
\end{tabular}

\section{Interpretation}

The correlation between the profitability and dividend payment of the firm is 0.314 . This represents a significant positive relationship between the profitability and dividend payout. This is because those more profitable companies pay more dividends. The profitability of a company is seen as significant factor of dividend payout. The correlation between the dividend payment and liquidity of the firm is 0.290 . This represents a significant positive association between the profitability and dividend payout. This depicts that position of cash flow or liquidity is the essential factors of dividend payout. The results of study recommend that a sound liquidity position enhance the company capability to pay dividends. In general, companies with good and stable liquidity can pay dividends easily compared to companies with unstable liquidity position.

The correlation between the dividend payment and leverage of the firm is -0.009 . This indicates that the relationship between leverage and dividend payment is negative and significant. This shows that higher debt leads to lower dividend payments to shareholders. This is because high-debt companies have a greater obligation to creditors in terms of debt repayment and interest. Since the main priority of the companies lies with the creditors, the amount that is distributed as a dividend to the shareholders, after payment of the debt obligations to the available balance is suspended, resulting in lower dividend payments. The correlation between the dividend payment and growth of the firm is -0.218 . This shows that there is a negative and significant relationship between growth and dividend payout ratio. This indicates that growing companies require more amount of funds in order to finance their growth opportunities. Therefore growing firms pay less amount of dividend out of their earrings to shareholder. They retain more portion of their earnings in order to meet there financial needs. The correlation between the dividend payment and business risk of the firm is -0.146 . This represents there is negative and statistically significant relationship between business risk and dividend payout. It means that, firms having high risk pay less amount of dividend to their shareholders, because they are experiencing high level of volatility in their earnings. Therefore such firms would not be able to pay dividend or pay less amount of dividend. On contrast, firms which have stable earnings they will easily predict the approximate future earnings and on the basis of these predicted earnings it is more likely that they will pay more percentage as dividend to their shareholders.

\subsection{Regression Results}

The regression analysis is applied on the panel data extracted from audited financial statements. Various panel data regression have been used, Fixed Effects, Random Effects and ordinary least square (OLS) Panel. Moreover the fixed effects model is prove to be most robust of all. The dividend payout is regressed by using the five explanatory variables. The variables are profitability, liquidity, leverage, business risk, and growth. The adjusted $\mathrm{R}$-square and calculated F-statistics represent that all the estimated model is a good fit to the data and the estimated model explains a significant variation in the dependent variable. Examining the estimated coefficient of leverage, liquidity and profitability shows significant positive relationship to the dividend policy of food companies in Pakistan. On the other hand, growth and business risk are negatively and significantly associated to the dividend policy. 
Table 4.4

Fixed Effect Model of the Panel Regression: Dependent Variable: Dividend Payout

\begin{tabular}{|c|c|c|c|c|}
\hline Variable & Coefficient & Std. Error & t-Statistic & Prob. \\
\hline $\mathrm{C}$ & 0.014 & 0.081 & 0.182 & 0.855 \\
\hline $\mathrm{BR}$ & -0.092 & 0.032 & -2.859 & 0.005 \\
\hline GR & -0.291 & 0.111 & -2.621 & 0.009 \\
\hline LE & 0.346 & 0.133 & 2.596 & 0.010 \\
\hline LIQ & 0.008 & 0.001 & 4.319 & 0.000 \\
\hline PRO & 1.667 & 0.318 & 5.227 & 0.000 \\
\hline R-squared & 0.321 & & & \\
\hline Adjusted $\boldsymbol{R}^{2}$ & 0.291 & & & \\
\hline F-statistic & 10.803 & & & \\
\hline Prob(F-statistic) & 0.000 & & & \\
\hline Hausman (P) & 0.002 & & & \\
\hline
\end{tabular}

BR (Business Risk), GR (Growth), LE (Leverage), LIQ (Liquidity), PRO (Profitability), DP (Dividend Payout)

Fixed Effect Model of the Panel Regression

In Hausman Test if the p-value is statistically significant, then we use fixed-effect model, otherwise random effect model. After applying Hausman Test, it was found that p-value 0.0026 were statistically significant. That is the alternative hypothesis was accepted and null hypothesis was rejected. The estimated coefficient of Profitability shows that significant positive relationship to the dividend payout. This is because of that highly profitable companies pay higher dividends. Therefore, they would have depicted high payout ratios. The profitability of a company is seen as significant factor impacting the dividend payout ratio. This result clearly supports our hypothesis. The findings of Yousof and Ismail (2014) and Imran (2011) are consistent with our results. The findings of Yousof and Ismail (2014) were positively and significantly related to dividend policy. Imran (2011) probed that a company has larger profitability they distributed more cash among the shareholder as a dividend. As expected, the estimated coefficient of liquidity reveals that it is positively and significantly related to the dividend payout. The cash flow or liquidity position is the essential factors of dividend payout. The results of this study recommend that a good liquidity position increases the company capability to pay dividends. In general, companies with good and stable liquidity can pay dividends easily compared to companies with unstable liquidity positions. The findings of Sanjari and Zarei (2015) are consistent with our results. Sanjari and Zarei (2015) found that Liquidity, leverage, and company size have significant and positive relationship with dividend payment. On the basis of our result we accept $\mathrm{H} 2$. The estimated coefficient of leverage shows that leverage is positively and significantly related to the dividend payout ratio. However, the company have make more debt financing, they can receive tax shield on their profit. Therefore they paid more dividends to their shareholder. On the other hand, the number of shareholders also remains the same. The similar results were also found by (Kowalewski et al., 2007; Ramli, 2010; Al-Shubiri, 2011). The findings of (chag and Rhee, 1990; Appannan and Sim, 2011; Gill et al., 2010) are consistent with our results. They found a positive relationship between debt financing and dividend policy. Sanjari and Zarei (2015) examined that leverage have significant positive relationship with dividend payment. On the basis of our result we accept H3. The estimated coefficient of business risk shows that it negatively and significantly related to the dividend payout. This shows that, firms with high risk pay less amount of dividend to their shareholders, because they are experiencing high level of volatility in their earnings. Therefore such firms would not be able to pay dividend or pay less amount of dividend. On contrast, firms which have stable earnings they will easily predict the approximate future earnings and on the basis of these predicted earnings it is more likely that they will pay more percentage as dividend to their shareholders. The findings of Gakumo and Nanjala (2016) are consistent with our results. Gakumo and Nanjala (2016) found that business risk negatively influence the dividend payout decision. On the basis of our result we accept H4.The result depicts that growth is negative but statistically significant liaison to the dividend payout. This indicates that growing firms need more amount of funds to finance their growth opportunities. Therefore growing firms pay less amount of dividend out of their earrings to shareholder. They retain more portion of their earnings in order to meet there financial needs. The findings of Amidu and Abur (2006) and Gul, khan, and Rehan (2013) are consistent with our results. Amidu and Abur (2006) found that risk, institutional shareholding, growth and market-to-book value were negatively related to the dividend payout. Gul, khan, and Rehan (2013) found that sale growth was negatively related to the dividend payout decision. On the basis of our result we reject $\mathrm{H}_{5}$.

\section{0: Conclusion, Implication and Suggestion for Future Research}

The aim of this study was to find the relationship of dividend policy with business risk, growth, leverage, 
liquidity and profitability of listed food companies in Pakistan. As expected, the regression coefficient shows that leverage, profitability and liquidity have positive relationships, while business risk and growth are inversely related to dividend policy. Primarily, leverage, profitability and liquidity have positive relations with the dividend policy. The higher the leverage, profitability and liquidity, higher the dividend amount, as these factors contribute to the decision of the dividend policy. Usually, if companies have a larger and more stable profit, the dividend paid to the shareholder will be higher. This result was supported by Ahmed and Javid (2009); Kowalewski et al. (2007); Al-Malkawi (2007) and Juma'h and Pacheco (2008). The liquidity is also in a positive relation to the dividend policy. This indicate that a good liquidity position enable the firm to pay dividend. This result is similar to Sanjari and Zarei (2015) and Ahmed \& Javid 2009). Leverage also led to a positive and significant relationship with dividend policy. This represent that on high debt financing company receive tax shield, therefore they pay high dividend to shareholder. This result is evidenced by (Chag \& Rhee, 1990, Kania \& Bacon (2005), Appannan \& Sim, 2011, Gill et al., 2010). The results also signifies negative relationship between growth, business risk and dividend payout. This indicates that firms with high risk, pay less amount of dividend to their shareholders, because they are experiencing high level of volatility in their earnings. Therefore such firms would not be able to pay dividend or pay less amount of dividend. The result was supported by Amidu \& Abur (2006); Gakumo \& Nanjala (2016); Fama \& French (1998). This indicates that growing firm needs more funds to finance their growth. Therefore they would retain large proportion of their earning and pay low dividend. The result was supported by Amidu \& Abur (2006); Gul, Khan \& Rehan (2013).

\subsection{Implications /Policy Recommendations}

The implication of this article is that the dividend policy of Pakistan-based food companies is influenced by business risk, growth, leverage, liquidity and profitability of companies. The study provides valuable information to the Board of Directors for formulating and reviewing the dividend policy, taking into account the factors that have been shown to have a significant impact on the dividend payout. In particular, if the Board of Directors considers increasing the dividend payment to shareholders, the factors of profitability, debt, liquidity, growth and business risk must be carefully considered. This is important because dividend policy is a key factor in keeping existing investors and attracting new investors. In addition, with high dividend payments attracting investors, the management team must strive for higher profitability, liquidity, leverage, and lower business risk and growth, to maximize the wealth and pay high dividend to shareholder.

\subsection{Future Research Direction /Out look}

Since the payment of dividends is a form of reward or return to shareholders, the results of this study provide valuable information to the existing and potential shareholder for making investment decision. The investor wants to invest in a company who has large profitability, liquidity, leverage and lower business risk and growth. Interestingly, future research could be conducted to check the combine effect of firm level factors, sector level factors and country level factors on dividend policy in non-financial sector.

\section{References}

Afza, T., \& Mirza, H. H. (2011). Do mature companies pay more dividends? Evidence from Pakistani stock market. Mediterranean Journal of Social Sciences, 2(2), 152-161

Amidu, M., \& Abor, J. (2006). Determinants of dividend payout ratios in Ghana. The journal of risk finance, 7(2), 136-145.

Al-Malkawi,H.A.(2007),"Determinants of corporate dividend policy in Jordan: anapplication of theTobitmodel",Journal of Economic and Administrative Sciences,Vol.23No.2,pp.44-70.

Asghar, M., Shah, S. Z. A., Hamid, K., \& Suleman, M. T. (2011). Impact of dividend policy on stock price risk: Empirical evidence from equity market of Pakistan.

Anjana, C. A., \& Balasubramanian, P. Determinants of Dividend Policy: A Study of Selected Listed Firms in National Stock Exchange.

Adhikari, N. (2015). Determinants of Corporate Dividend Payout in Nepal. NRB Economic Review, 27(2), 1-22.

Anil, K., \& Kapoor, S. (2008). Determinants of dividend payout ratios-a study of Indian information technology sector. International Research Journal of Finance and Economics, 15(1), 63-71.

Al-Shubiri, F. N. (2011). Determinants of changes dividend behavior policy: Evidence from the Amman Stock Exchange. Far East Journal of Psychology and Business, 4(1), 1-15.

Awad, B. (2015). Determinates of dividend policy in kuwait stock exchange. International journal of business and management, 3(7).

Arif, A., \& Akbarshah, F. (2013). Determinants of dividend policy: a sectoral analysis from Pakistan. International Journal of Business and Behavioral Sciences Vol. 3, No.9

Al-Kuwari, D. (2009). Determinants of the Dividend Policy of Companies Listed on Emerging Stock Exchanges: The Case of the Gulf Cooperation Council (GCC) Countries. Global Economy \& Finance Journal Vol.2, p. 
38-63

Al-Shabibi, B.K. and Ramesh, G. (2011), "An empirical study on the determinants of dividend policy in the UK", International Research Journal of Finance and Economics, Vol. 80, pp.105-120

Ahmed, H. and Javid, A.Y. (2009), "The determinants of dividend policy in Pakistan", International Research Journal of Finance and Economics, Vol. 29, pp. 110-125.

Bushra, A. (2012). The Determinants of Corporate Dividend Policy in Pakistan (Doctoral dissertation, (C) Lahore Schoool of Economics). The Lahore Journal of Economics 20: 2 (Winter 2015): pp. 77-98

Bhattacharya, S. (1979). Imperfect information, dividend policy, and" the bird in the hand" fallacy. The Bell Journal of Economics, 259-270.

Charitou, A. (2000). The impact of losses and cash flows on dividends: Evidence for Japan. Abacus, 36(2), 198225.

Baker, M., \& Wurgler, J. (2004). A catering theory of dividends. The Journal of Finance, 59(3), 1125-1165.

Brennan, M. J. (1970). Taxes, market valuation and corporate financial policy. National tax journal, 23(4), 417427.

Charitou, A. (2000). The impact of losses and cash flows on dividends: Evidence for Japan. Abacus, 36(2), 198225.

Chang, R. P., \& Rhee, S. G. (1990). The impact of personal taxes on corporate dividend policy and capital structure decisions. Financial Management, 21-31.

DeAngelo, H., \& Masulis, R. W. (1980). Leverage and dividend irrelevancy under corporate and personal taxation. The Journal of Finance, 35(2), 453-464.

DeAngelo, H., DeAngelo, L., \& Skinner, D. J. (2004). Are dividends disappearing? Dividend concentration and the consolidation of earnings. Journal of Financial Economics, 72(3), 425-456.

Denis, D. J., \& Osobov, I. (2008). Why do firms pay dividends? International evidence on the determinants of dividend policy. Journal of Financial economics, 89(1), 62-82.

Dai, J., \& Ringborg, F. (2016). Determinants of Dividend Policy in Sweden.http://lup.lub.lu.se/luur/download?func=downloadFile\&recordOId=8892231\&fileOId=8892237

Elton, E., \& Gruber, M. (1970). Marginal Stockholder Tax Rates andthe Clientele Effect. Review of Economics and Statistics (February 1970), 68-74.

Foroghi, D., Karimi, F., \& Momeni, Z. (2011). The investigation relationship of dividend behavior and likelihood of paying dividend with financial tehran stock exchange. Interdisciplinary Journal of contemporary Research in Business, 3, 390-397.

F. Perretti, G., T. Allen, M., \& Shelton Weeks, H. (2013). Determinants of dividend policies for ADR firms. Managerial Finance, 39(12), 1155-1168.

Forti, C. A. B., Peixoto, F. M., \& Alves, D. L. (2015). Determinant Factors of Dividend Payments in Brazil. Revista Contabilidade \& Finanças, 26(68), 167-180

Farinha, J. (2003). Dividend policy, corporate governance and the managerial entrenchment hypothesis: an empirical analysis. Journal of Business Finance \& Accounting, $30(9$ - 10), 1173-1209.

Gill, A., Biger, N., \& Tibrewala, R. (2010). Determinants of dividend payout ratios: evidence from United States. The Open Business Journal, 3(1).

Grullon, G., Michaely, R., \& Swaminathan, B. (2002). Are dividend changes a sign of firm maturity?. The Journal of Business, 75(3), 387-424.

Gakumo, S. T., \& Nanjala, C. (2017). Factors influencing dividend payout decision of financial and nonfinancial companies listed on Nairobi securities exchange. American Journal of Finance, 1(2), 16-29.

Gomes Almeida, L. A., Teixeira Pereira, E., \& Oliveira Tavares, F. (2015). Determinants of dividend policy: evidence from Portugal. Revista Brasileira de Gestão de Negócios, 17(54).

Hashemi, S. A., \& Zadeh, Z. K. (2012). The Impact of Financial Leverage, Operating Cash Flow and Size of Company on the Dividend Policy (Case Study of Iran). Interdisciplinary Journal of Contemporary Research in Business, 3(10), 264-270.

Ho, H. (2003). Dividend policies in Australia and Japan. International Advances in Economic Research, 9(2), 91-100.

Imran, K. (2011). Determinants of dividend payout policy: A case of Pakistan engineering sector. The Romanian Economic Journal, 41, 47-60.

Jensen, M. C., \& Meckling, W. H. (1976). Theory of the firm: Managerial behavior, agency costs and ownership structure. Journal of financial economics, 3(4), 305-360.

Jensen, M. C. (1986). Agency costs of free cash flow, corporate finance, and takeovers. The American economic review, 76(2), 323-329.

Juma'h, A. H., \& Pacheco, C. J. (2008). The financial factors influencing cash dividend policy: A sample of US manufacturing companies. Inter Metro Business Journal, 4(2), 23-43.

Khan, M. N., Naeem, M. U., Rizwan, M., \& Salman, M. (2016). Factors Affecting the Firm Dividend Policy: An 
Empirical Evidence from Textile Sector of Pakistan. International Journal of Advanced Scientific Research and Management, 1(5), 144-149.

Kania, S. L. (2005). What factors motivate the corporate dividend decision?.http://digitalcommons.longwood.edu/cgi/viewcontent.cgi?article=1192\&context=etd

Khang, K., \& King, T. H. D. (2006). Does Dividend Policy Relate to Cross - Sectional Variation in Information Asymmetry? Evidence from Returns to Insider Trades. Financial Management, 35(4), 71-94

Kumar, J. (2006). Corporate governance and dividends payout in India. Journal of Emerging Market Finance, 5(1), 15-58.

Kowalewski, O., Stetsyuk, I., \& Talavera, O. (2007). Do corporate governance and ownership determine dividend policy in Poland? Bank i Kredyt, (11-12), 60-86.

Kaźmierska-Jóźwiak, B. (2015). Determinants of Dividend Policy: Evidence from Polish Listed Companies. Procedia Economics and Finance, 23, 473-477.

Kent Baker, H., Saadi, S., Dutta, S., \& Gandhi, D. (2007). The perception of dividends by Canadian managers: new survey evidence. International Journal of Managerial Finance, 3(1), 70-91.

Kayo, E. K., \& Kimura, H. (2011). Hierarchical determinants of capital structure. Journal of Banking \& Finance, 35(2), 358-371

Kale, J. R., \& Noe, T. H. (1990). Dividends, uncertainty, and underwriting costs under asymmetric information. Journal of Financial Research, 13(4), 265-277.

Kumar, B. R., \& Waheed, K. A. (2014). Determinants of dividend policy: Evidence from GCC market. Accounting and Finance Research, 4(1), 17.

Kuzucu, N. (2015). Determinants of Dividend Policy: A Panel Data Analysis for Turkish Listed Firms. International Journal of Business and Management, Vol. 10, No. 11.

Lee, S. W. (2009). Determinants of dividend policy in Korean banking industry. Banks and Bank Systems, 4(1), 67-71.

Litzenberger, R. H., \& Ramaswamy, K. (1979). The effect of personal taxes and dividends on capital asset prices: Theory and empirical evidence. Journal of financial economics, 7(2), 163-195.

Lintner, J. (1956). Distribution of incomes of corporations among dividends, retained earnings, and taxes. The American Economic Review, 46(2), 97-113.

Mehrani, S., Moradi, M., \& Eskandar, H. (2011). Ownership structure and dividend policy: Evidence from Iran. African Journal of Business Management, 5(17), 7516.

Mehta, A. (2012). An empirical analysis of determinants of dividend policy-evidence from the UAE companies. Global Review of Accounting and Finance, 3(1), 18-31.

Malik, F., Gul, S., Khan, M. T., Rehman, S. U., \& Khan, M. (2013). Factors influencing corporate dividend payout decisions of financial and non-financial firms. Research Journal of Finance and Accounting, 4(1), $35-46$.

Muqaddas, I. A. M. F. Determinants of dividend payout policy: an empirical study of banking sector of Pakistan. http://ageconsearch.tind.io/record/257113/files/Apstract_2016_04-05_vol10_13_fejezet.pdf.

Mat, N. C., Mokhtar, N. A., Ali, S., Kasim, K., \& Zani, R. M. (2017). The determinants of dividend policy of public listed companies in Malaysia. Journal of Humanities, Language, Culture and Business, Vol (1), page $36-47$

Miller, M. H., \& Modigliani, F. (1961). Dividend policy, growth, and the valuation of shares. the Journal of Business, 34(4), 411-433.

Musiega, M. G., Alala, O. B., Douglas, M., Christopher, M. O., \& Robert, E. (2013). Determinants of Dividend Payout Policy among Non-Financial Firms on Nairobi Securities Exchange, Kenya. International journal of scientific \& Technology Research, 2(10), 253-266.

Myers, S. C., \& Majluf, N. S. (1984). Corporate financing and investment decisions when firms have information that investors do not have. Journal of financial economics, 13(2), 187-221.

Nnadi, M., Wogboroma, N., \& Kabel, B. (2013). Determinants of dividend policy: Evidence from listed firms in the African stock exchanges. Panoeconomicus, 60(6), 725-741.

Pruitt, S. W., \& Gitman, L. J. (1991). The interactions between the investment, financing, and dividend decisions of major US firms. Financial review, 26(3), 409-430.

.Rozeff, M. S. (1982). Growth, beta and agency costs as determinants of dividend payout ratios. Journal of financial Research, 5(3), 249-259.

Rafique, M. (2012). Factors affecting dividend payout: Evidence from listed non-financial firms of Karachi stock exchange. Business Management Dynamics, 1(11), 76-92.

Ramli, N.M. (2010), "Ownership structure and dividend policy: evidence from Malaysian companies", International Review of Business Research Papers, Vol. 16 No. 1, pp. 170-180

Renneboog, L., \& Szilagyi, P. G. (2008). Corporate restructuring and bondholder wealth. European Financial Management, 14(4), 792-819. 
Skinner, D. J., \& Soltes, E. (2011). What do dividends tell us about earnings quality. Review of Accounting Studies, 16(1), 1-28.

Sterk, W. E., \& Vandenberg, P. A. (1990). The market valuation of cash dividends and the tax differential theory of dividend policy: a case revisited. Financial Review, 25(3), 441-455.

Smith, C. W., \& Watts, R. L. (1992). The investment opportunity set and corporate financing, dividend, and compensation policies. Journal of financial Economics, 32(3), 263-292.

Utami, S. R., \& Inanga, E. L. (2011). Agency costs of free cash flow, dividend policy, and leverage of firms in Indonesia. European Journal of Economics, Finance and Administrative Sciences, 33(6), 7-24.

Yusof, Y., \& Ismail, S. (2016). Determinants of dividend policy of public listed companies in Malaysia. Review of International Business and Strategy, 26(1), 88-99.

\section{Authors Biography}

Kamran Ullah1; MS Finance and Management Sciences, University of Shaheed Zulfikar Ali Bhutto , Institute of science and technology, Islamabad, Department of management Sciences, Pakistan; Tanveer Bagh2*; Finance and Management Scholar at Riphah International University Islamabad, Pakistan, Faculty of Management Sciences, Riphah School of Leadership, MBA Finance, Department of Business Administration (UAJ\&K), Pakistan, Lecturer Banking Finance and Accounting at Indus Group of College; Dr.Muhammad Arif 3; PhD in Corporate Finance, Department of Management Sciences, Assistant Professor, University of Sawabi KPK, Pakistan 